\title{
ONLINE APPLICATION AS A TOOL FOR PEDAGOGICAL DIAGNOSTICS IN PRESCHOOL EDUCATION
}

Eva $\breve{S} \boldsymbol{M E L O V} \boldsymbol{A}^{*}$, Univerzita Palackého v Olomouci, Česká republika Dominika PROVÁZKOVÁ STOLINSKÁ, Univerzita Palackého v Olomouci,

Česká republika

Pavlína ČÁSTKOVÁ, Univerzita Palackého v Olomouci, Česká republika, Alena PETROVÁ, Ostravská univerzita v Ostravě, Česká republika, Irena PLEVOVÁ, Univerzita Palackého v Olomouci, Česká republika, Jan KUBRICKÝ, Univerzita Palackého v Olomouci, Česká republika,

Přijato: 14. 1. 2020 / Akceptováno: 3. 2. 2021

Typ článku: Teoretická studie

DOI: DOI: $10.5507 /$ jtie. 2021.004

Abstract: The paper presents an online application as a tool of pedagogical diagnostics for preschool education, which was created as an original tool within the project of the Technology Agency of the Czech Republic. The three-year project responds to the current needs of pedagogical practice in the context of pedagogical diagnostics, but also to the conditions of education during the covid epidemic. The text describes the basis for creating the application, its technology and pedagogical concept. At the same time, the reader can get acquainted with the implementation of the application in practice, especially with the pros and cons of kindergarten teachers who are involved in the project and are among the first users of the created application.

Key words: article, journal, principle, lack, template.

\section{ONLINE APLIKACE JAKO NÁSTROJ PEDAGOGICKÉ DIAGNOSTIKY V PŘEDŠKOLNÍM VZDĚLÁVÁNÍ}

Abstrakt: Autoři př́spěvku si kladou za cíl představit online aplikaci jako nástroj pedagogické diagnostiky pro předškolni vzdělávání, která byla vytvořena jako originálni nástroj v rámci projektu Technologické agentury $\check{C} R$. Tř́letý projekt reaguje na aktuálni potřby pedagogické praxe $v$ kontextu pedagogické diagnostiky, ale současně, i na podmínky vzdělávání v době covidové epidemie. $V$ textu jsou popsána východiska pro tvorbu aplikace, její technologie i pedagogický koncept. Čtenár se může současně seznámit s implementaci aplikace do praxe, zejména potom s klady a pripomínkami ze strany učiteli mateřských škol, kteř́ jsou do projektu zapojeni, a patř́ k prvním uživateliom vytvořené aplikace.

Klíčová slova: článek, časopis, zásada, nedostatek, šablona.

*Autor pro korespondenci: eva.smelova@upol.cz 


\section{1 Úvod}

V České republice je od roku 2017 uzákoněno povinné předškolní vzdělávání, a to poslední rok před zahájením povinné školní docházky. K zavedení povinné předškolní docházky došlo s cílem zkvalitnit př́pravu dětí $\mathrm{k}$ zahájení povinné školní docházky a současně snížit odklady nástupu do povinného základního vzdělávání viz tab. 1 . Z tabulky je taká zřejmé vysoké procento zaškolení tj. dětí ve věku 5 let.

\begin{tabular}{|l|l|l|l|l|l|l|}
\hline Věk & $\begin{array}{l}\mathbf{2 0 1 4} / \mathbf{1} \\
\mathbf{5}\end{array}$ & $\begin{array}{l}\mathbf{2 0 1 5} / \mathbf{6} \\
\mathbf{6}\end{array}$ & $\begin{array}{l}\mathbf{2 0 1 6} / \mathbf{1} \\
\mathbf{7}\end{array}$ & $\begin{array}{l}\mathbf{2 0 1 7 / 1} \\
\mathbf{8}\end{array}$ & $\begin{array}{l}\mathbf{2 0 1 8} / \mathbf{1} \\
\mathbf{9}\end{array}$ & $\begin{array}{l}\mathbf{2 0 1 9} / \mathbf{0} \\
\mathbf{0}\end{array}$ \\
\hline mladší než 2 roky & $0,7 \%$ & $0,8 \%$ & $0,8 \%$ & $0,7 \%$ & $0,6 \%$ & $0,4 \%$ \\
\hline 2leté ${ }^{1)}$ & $33,9 \%$ & $38,1 \%$ & $39,3 \%$ & $39,9 \%$ & $39,3 \%$ & $36,9 \%$ \\
\hline 3leté & $84,1 \%$ & $82,5 \%$ & $83,9 \%$ & $82,1 \%$ & $82,7 \%$ & $82,8 \%$ \\
\hline 4leté & $89,4 \%$ & $94,4 \%$ & $91,0 \%$ & $91,5 \%$ & $89,1 \%$ & $89,9 \%$ \\
\hline 5leté & $90,5 \%$ & $91,8 \%$ & $96,4 \%$ & $95,2 \%$ & $95,8 \%$ & $93,0 \%$ \\
\hline 6leté & $16,5 \%$ & $17,0 \%$ & $17,0 \%$ & $18,7 \%$ & $18,7 \%$ & $19,4 \%$ \\
\hline starší než 6 let & $0,2 \%$ & $0,2 \%$ & $0,1 \%$ & $0,1 \%$ & $0,1 \%$ & $0,1 \%$ \\
\hline
\end{tabular}

Tab. 1 Věkové zastoupeni dětí v předškolním vzdělávání (databáze MŠMT, ČSÚ)

Plnění povinnosti předškolního vzdělávání se rozumí:

a) individuální vzdělávání dítěte, které se uskutečňuje bez pravidelné denní docházky dítěte do mateřské školy,

b) vzdělávání v přípravné třídě základní školy a ve třídě přípravného stupně základní školy speciální,

c) vzdělávání v zahraniční škole na území České republiky, ve které ministerstvo školství povolilo plnění povinné školní docházky.

Povinné předškolní vzdělávání se nevztahuje na děti s hlubokým mentálním postižením.

Po absolvování povinné předškolní docházky by mělo dítě nastoupit do povinného základního vzdělávání. Podmínkou je školní zralost a dovršení šestého roku. Není-li dítě tělesně nebo duševně přiměřeně vyspělé a požádá-li o to písemně zákonný zástupce dítěte v době zápisu dítěte $\mathrm{k}$ povinné školní docházce, odloží ředitel školy začátek povinné školní docházky o jeden školní rok, pokud je žádost doložena doporučujícím posouzením příslušného školského poradenského zařízení a odborného lékaře nebo klinického psychologa. Začátek povinné školní docházky lze odložit nejdéle do zahájení školního roku, v němž dítě dovrší osmý rok věku.

Předškolní vzdělávání zde sehrává důležitou roli a ve spolupráci s rodinou dítěte se podílí na jeho rozvoji a cílené prrípravě k zahájení povinné školní docházky. Jak již jsme se zmínili důležitým ukazatelem pro vstup do základního vzdělávání je nejen věk, ale také školní zralost, která je předpokladem úspěšného počátku školní docházky, což významně ovlivňuje vytváření pozitivního vztahu žáka ke vzdělávání a učení. (Šmelová, 2019, s. 144 - 146) 


\section{Předškolní kurikulum prostř̌edek pokroků dítěte}

Česká republika má vytvořený systém rámcových vzdělávacích programů, jehož nedílnou součástí je Rámcový vzdělávací program pro předškolní vzdělávání (dále kurikulum). Rámcové vzdělávací programy stanoví zejména konkrétní cíle, formy, délku a povinný obsah vzdělávání, jeho organizační uspořádání, podmínky průběhu a ukončování vzdělávání a zásady pro tvorbu školních vzdělávacích programů, jakož i podmínky pro vzdělávání žáků se speciálními vzdělávacími potřebami a nezbytné materiální, personální a organizační podmínky a podmínky bezpečnosti a ochrany zdraví.

$\mathrm{Na}$ základě kurikula na státní úrovni si mateřské školy tvoří s ohledem na vlastní podmínky školní vzdělávací programy.

Předškolní kurikulum staví na základních principech, na nichž je předškolní vzdělávání realizované tak, aby:

- akceptovalo přirozená vývojová specifika dětí předškolního věku a důsledně je promítal do obsahu, forem a metod jejich vzdělávání,

- umožňovalo rozvoj a vzdělávání každého jednotlivého dítěte $\mathrm{v}$ rozsahu jeho individuálních možností a potřeb,

- zaměřovalo se na vytváření základů klíčových kompetencí dosažitelných v etapě předškolního vzdělávání,

- definovalo kvalitu předškolního vzdělávání z hlediska cílů vzdělávání, podmínek, obsahu i výsledků, které má prrinášet,

- zajišt'ovalo srovnatelnou pedagogickou účinnost vzdělávacích programů vytvářených a poskytovaných jednotlivými mateřskými školami,

- vytváŕelo prostor pro rozvoj různých programů a koncepcí i pro individuální profilaci každé mateřské školy,

- umožňovalo mateřským školám využívat různé formy i metody vzdělávání a přizpůsobovat vzdělávání konkrétním regionálním i místním podmínkám, možnostem a potřebám,

- poskytoval rámcová kritéria využitelná pro vnitřní i vnější evaluaci mateřské školy i poskytovaného vzdělávání. (RVP PV 2018, s. 5)

Koncepce předškolního vzdělávání je založena na týchž zásadách jako ostatní obory a úrovně vzdělávání a řídí se s nimi společnými cíli: orientuje se $\mathrm{k}$ tomu, aby si dítě od útlého věku osvojovalo základy klíčových kompetencí a získávalo tak předpoklady pro své celoživotní vzdělávání, umožňující mu se snáze a spolehlivěji uplatnit ve společnosti znalostí. Má usnadňovat dítěti jeho další životní i vzdělávací cestu.

Úkolem učitele je proto rozvíjet osobnost dítěte, podporovat jeho tělesný rozvoj a zdraví, jeho osobní spokojenost a pohodu, napomáhat mu v chápání okolního světa a motivovat je k dalšímu poznávání a učení, stejně tak i učit dítě žít ve společnosti ostatních a přibližovat mu normy a hodnoty touto společností uznávané. Dalším důležitým úkolem je vytvářet dobré předpoklady pro pokračování ve vzdělávání tím, že za všech okolností budou maximálně podporovány individuální možnosti rozvoje dětí a bude tak každému dítěti umožňováno dospět $\mathrm{v}$ době, kdy opouští mateřskou školu, $\mathrm{k}$ optimální úrovni osobního rozvoje a učení, resp. k takové úrovni, která je pro dítě individuálně dosažitelná.

$Z$ výše uvedeného je zřejmé, že na základě každodenního styku s dítětem i jeho rodiči plní předškolní vzdělávání i úkol diagnostický. Pedagogická diagnostika patří ke 
každodenní práci učitelů. Průběžná, systematická činnost učitele směřuje k pedagogické diagnóze, a to na základě pozorování, rozhovorů s rodiči, analýze dětstvích výtvorů apod. Učitel tak prristupuje k dítěti rozvoj s ohledem na jeho možnosti, potřeby a zájmy. Pomáhá mu překonávat překážky, eliminovat možné deficity. Postupně dítě připravuje na roli školáka.

\section{Předpoklady úspěšného počátku povinné školní docházky}

Tradičně existuje velký zájem o všechny činitele, kteří mohou mít podíl na míre úspěšnosti, s níž se dítě vyrovnává s požadavky povinné školní docházky. Je velmi podstatné, zda vývojové změny dítěte dosáhly $\mathrm{v}$ období jeho nástupu do školy přiměřené úrovně a kvality. Přihlédneme-li v této souvislosti k vývojovým zákonitostem, pak nás nepřekvapí skutečnost, že ne vždy jsou děti stejného věku po stránce fyzické i psychické stejně rozvinuty. Školní úspěšnost je tak výrazně ovlivněna jak vrozenými dispozicemi dítěte, tak celkovým dosavadním průběhem jeho vývoje, zvláště pak charakterem rodinného prostředí a výchovy. $\mathrm{K}$ tomu přistupuje významné působení mateřských škol, které často může zmírnit nedostatky málo podnětného rodinného prostředí.

Způsobilost pro školní práci dělí někteř́i autoři (např. Vágnerová, 2005) na školní zralost a školni připravenost. Školní zralostí bývají myšleny předpoklady související především s biologickým zráním celého organismu dítěte, především centrálního nervového systému. Školní připraveností se pak myslí spíše dovednosti získané výchovou, tedy související s vlivy prostředí. Vzhledem k dynamické interakční povaze vlivů vrozených dispozic a prostředí navrhují někteří autoři (např. Thorová, 2015; Langmeier, Krejčířová, 2008) jako vhodnější použivat jednotný pojem školní zralost, který chápou jako pojem komplexní, zahrnující jak zralost, tak připravenost, tedy domény ovlivněné zráním i učením (subjektivní zkušeností).

Obecně lze tedy chápat školní zralost jako takový stupeň vývoje tělesných i duševních schopností a dovedností dítěte, který je nutným předpokladem úspěšného zvládnutí školních požadavků. $\mathrm{O}$ jaké předpoklady konkrétně jde, nám mohou přibližit somatopsychická posuzovací kritéria, která je však potřeba chápat ve vzájemné součinnosti a s ohledem na individualitu dítěte i jeho dosavadní životní historii. Důležitá kvalitní, průběžně realizovaná diagnostika projevů dítěte $v$ jednotlivých oblastech. Je potřeba vyzdvihnout roli předškolního pedagoga, jehož dlouhodobé pozorování projevů dítěte a možnost srovnávání s vrstevníky jsou nenahraditelným zdrojem informací.

\section{1 Tělesné předpoklady úspěšného zaškolení}

$\mathrm{N}$ této úrovni bývají posuzovány nejčastěji následující znaky:

- věk dítěte, jeho výška a hmotnost,

- dokončení 1 . strukturální přeměny,

- celkové zdraví dítěte, 
- zrání jeho organismu, především CNS, které je předpokladem pro další projevy (práce smyslů, přiměřenost rozvoje hrubé motoriky a pohybové koordinace, lateralita, autoregulace, vyspělost jemné motoriky apod.).

Pokusme se je alespoň stručně přiblížit. V období kolem vstupu do školy se nápadně mění tělesné proporce dítěte (Thorová, 2015). Těsně před šestým rokem probíhá tzv. první strukturální přeměna, v jejímž rámci pozorujeme vymizení dětské zaoblenosti i výrazu, dochází $\mathrm{k}$ celkovému protažení postavy dítěte, hrudník se zřetelněji odlišuje od břicha, prodlužují se končetiny (tradiční orientací je tzv. filipinská míra), dochází k osifikaci zápěstních kůstek, upevnění zádového svalstva a započetí druhé dentice (stav dentice dobře vystihuje „věk organismu“), vyzrávají funkce CNS. Samo dosažení věkové hranice 6-ti let nemusí znamenat priměřenou fyzickou zralost.

V úvahu je nutno vzít i rozdíly pohlaví, děvčata obvykle mírně předbíhají ve svém vývoji chlapce, tito mívají vývoj nerovnoměrnější (Thorová, 2015). Učitel 1. tř́́dy se tak setkává s dětmi sotva šestiletými, ale i sedmiletými či staršími a tuto skutečnost rozdílu by měl zohlednit (Langmeier, Krejčírová, 2008; Matějček, 1994). Určitý přiměřený stupeř zralosti CNS je podmínkou úspěšného záměrného učení, souvisí s efektivním fungováním psychických funkcí a procesů. Př́liš časné učení je obtížné a zdlouhavé oproti učení, které nastupuje ve vhodnou dobu.

Pro úspěšný školní start je významná také úroveň motorického vývoje dítěte (přiměřená vyspělost hrubé i jemné motoriky). Dítě by mělo být schopné vykonávat komplexní pohybové činnosti jako plavání, jízda na kole, různé sportovní aktivity (Thorová, 2015).

Pohybová koordinace s sebou přináší celkové motorické zklidnění, dítě neplýtvá silami, jeho pohyby jsou úsporné, efektivní (ve srovnání s předškolákem), má radost z pohybu, ale dovede ho i usměrnit, zvládne drobné přesné pohyby (což je patrné $\mathrm{v}$ kresbě a psaní). Důležitým momentem v této souvislosti je správné držení tužky či pastelky.

Nejpozději před vstupem do školy by měli dospělí kolem dítěte vypozorovat jeho typ laterality. Je totiž nutné stanovit, kterou rukou se bude dítě učit psát. Kolem 6. roku dozrává i koordinace očních pohybů, důležitá pro kvalitativní změny ve vnímání (viz dále).

\section{2 Kognitivní předpoklady školní úspěšnosti}

U dítěte na prahu školní docházky zjišt’ujeme prohloubenou diferenciaci jednotlivých mentálních funkcí a jejich narůstající integraci. K posuzovacím kritériím kognitivní zralosti bývají zařazovány následující jevy (Vágnerová, 1997, 2005, Langmeier, Krejčířová, 2008, Thorová, 2015 aj.):

- přechod od celostního k pročleněnému (analytickému) vnímání

- celková schopnost využití analýzy a syntézy v poznání,

- schopnost konkrétních myšlenkových operací při zacházení s názorným materiálem

- $\quad$ schopnost krátkodobé záměrné paměti, $\mathrm{v}$ rámci níž se objevují i logické prvky

- odlišení reality a světa fantazie, sklon k realismu,

- překonávání egocentrismu (v poznávací i sociální oblasti),

- počátky vůlí ovládané pozornosti, 
- $\quad$ zvídavost a tvořivý, aktivní prístup ke světu,

- přiměřený vývoj řeči (plynulá řeč ve větách, gramatická a artikulační správnost)

- $\quad$ rozlišení hry a povinnosti (vytrvalost při úkolu, oddálení spontánních přání a impulsů).

Přechod od globálního, celostního vnímáni $k$ analytickému, pročleněnému umožñuje dítěti diferencovat vizuální a zvukové prvky (jde o nevyhnutelný předpoklad úspěchu ve čtení, psaní, počítání). Školák musí být schopen rozlišovat detaily, mezi nimiž jsou nějaké vztahy, z vnímaného celku vyčleňovat části a původní celek opět složit. Jde o schopnost analyticko-syntetické činnosti.

Školsky zralé dítě chápe skutečnost realisticky a začíná logicky myslet, pochopitelně ve spojitosti s konkrétními předměty a činnostmi. Zralá vizuální a sluchová krátkodobá (pracovní) pamět' jsou nezbytnými předpoklady nácviku čtení a psaní (Thorová, 2015). Přechod od mimovolního, spontánního zapamatování k úmyslnému a konkrétné logickému úzce souvisí se změnami v oblasti pozornosti. Stěžejní význam má totiž violi ovládaná koncentrace pozornosti. Úspěšný žák zvládá aktivně vnímat a soustředit se na to, co se mu přikazuje, je schopen úmyslné pozornosti (z počátku můžeme počítat s časovým úsekem jen kolem 10 minut).

Velký vliv na školní úspěšnost má kvalitativní úroveň řeči (předpokladem je řeč ve větách a jednodušších souvětích, bez agramatismů a vad výslovnosti, s přiměřenou slovní zásobou). Dětská patlavost, tzv. dyslálie, by měla být $\mathrm{v}$ období nástupu do školy již překonána (doporučuje logopedická péče, nejlépe po 5. roce. Údaje o rozsahu aktivní slovní zásoby jsou v literatuře nejednotné, nejčastěji bývá udáván pro šestileté dítě potřebný rozsah 3-4 tisíce slov (zároveň dítě rozumí širšímu rozsahu, a to především podle kvality podnětů z okolí).

K typickým rysům školsky úspěšného dítěte patří zvídavost a tvořivý přístup ke světu. Dítě má zájem o nové poznatky a dovednosti, je aktivní a schopné vytrvalejší, cílevědomé činnosti.

\section{3 Emoční, motivační a sociální předpoklady}

Zahrnují (Thorová, 2015; Langmeier, Krejčířová, Vágnerová, 1997, 2005 aj.):

- $\quad$ adaptaci na novou roli žáka a spolužáka, adaptaci na režim školy,

- $\quad$ kontrolu či odsunutí okamžitých nápadů a impulzů, přijetí autority učitele,

- odpovídající pracovní tempo, kladný přístup k učení, ochota spolupracovat,

- bezproblémové začlenění se do skupiny vrstevníků, schopnost dočasného odloučení od rodiny (menší závislost na rodičích), schopnost empatie a zapojení se do prosociálních aktivit,

- přiměřená kontrola citů a impulzů, relativní emocionální stabilita a odolnost vůči frustracím a zátěžovým podnětům,

- kladný postoj $\mathrm{k}$ sobě, přiměřená sebedůvěra a iniciativa, určitá míra samostatnosti. 
Do vstupu dítěte do školy se formuje jeho základní emoční výbava, její strategie a programy, které si dítě nese do dalších období svého života. Emoční a sociální zdatnost hrají při zařazení dítěte do školy významnou roli. Školní úspěšnost souvisí s vytvořením kladného postoje dítěte ke škole, $\mathrm{k}$ učiteli, ke spolužákům, s pocitem, že všechno zvládne, necítí se zaskočeno, zavaleno školními nároky.

Emoční a sociální zralost se vyznačují kontrolou citů a impulzů, schopností pobývat bez úzkosti mimo svou rodinu v kolektivu vrstevníků, umět s nimi komunikovat, přijmout novou roli žáka a spolužáka, podř́idit se autoritě učitele. Thorová (2015) zdůrazñuje, že školsky zralé dítě vykazuje zájem o široký okruh informací, zajímá se o fakta a souvislosti, zvládne kratší dobu pracovat samostatně, přiměřeným tempem a přiměřenou pečlivostí. Vágnerová (2005) se zase zmiňuje o důležitosti dovednosti odložit splnění momentálních přání, podř́dit se určitému režimu, usměrnit svou potřebu pohybu, nedožadovat se pozornosti a usměrnit další osobní potřeby, pokud to vyžaduje společný cíl či společně prováděný úkol. Podstatnou roli hraje prožitek v situacích hodnocení a srovnávání výkonů dětí učitelem, který významně zasahuje do formování sebedůvěry a sebecitu. Zvláště pro školní počátek platí známá zásada - zabezpečit alespoň jeden úspěch a radostný zážitek denně pro každého i toho nejslabšího žáka.

\section{Online aplikace - nástroj pedagogické diagnostiky v práci učitele mateřské školy}

\subsection{Východiska realizovaného developmentu}

Základním kritériem pro posuzování pokroků dítěte, tedy i pro posuzování školní zralosti a připravenosti jsou předškolním kurikulem stanovené klíčové kompetence a tzv. očekávané výstupy. Jsou v podobě znalostí, dovedností, postojů, schopností atd., kterých by mělo dítě dosáhnout na konci předškolního vzdělávání. Nastavené výstupy nejsou dané jako pevné normy, nebot' každé dítě je posuzováno z hlediska vlastních individuálních možností. Míra dosažení či nedosažení je ukazatelem, zda je dítě připravené zahájit povinnou školní docházku.

Mateřské školy si vytvářejí vlastní metodiky pro pedagogickou diagnostiku. V rámci průzkumů se ukazuje, že školy často přebírají různé z odborných, ale i popularizačních publikací záznamové archy, které ale nedokáží dostatečně propojit s výstupy kurikula. Daná skutečnost se potom odráží nejenom v projektování školního kurikula, ale i v každodenní pedagogické práci učitele. Nedostatečná konzistence mezi stanovenými výstupy kurikula jako ukazateli školní připravenosti a oblastmi stanovenými pro posuzování dítěte $\mathrm{v}$ rámci vlastní pedagogické diagnostiky může vést $\mathrm{k}$ nedostatečnému rozvoji některých zvlášt' důležitých dovedností, které tvoři důležitou vybavenost pro budoucího prvňáčka. K častým problémům patří řečový rozvoj, grafomotorika a s ní spojený nesprávný úchop tužky, ale i oblast sociálních dovedností. Pokud se podíváme do některých školních vzdělávacích programů, tř́dních plánů a záznamových archů zjistíme, že chybí provázanost, zaměření se na klíčové oblasti nastavené v kurikulu. Danou problematikou se zabýváme již od počátků zavádění rámcových vzdělávacích programů a můžeme konstatovat, že propojenost kurikula a třídních plánů s posuzováním dítěte $\mathrm{v}$ kontextu kompetencí či očekávaných výstupů a na základě pedagogické diagnostiky přetrvávají. Tato skutečnost nás vedla $\mathrm{k}$ vytvoření online aplikace pro potřeby pedagogické diagnostiky, která by zajistila systematický př́stup $\mathrm{k}$ rozvoji dítěte, $\mathrm{k}$ jeho posuzování, ale 
také dokázala upozornit na problematické oblasti, kde je nutná zvýšená podpora ze strany učitele. $V$ době technologií se nám odklon od záznamů ve formě „tužka - papír“ zdál zcela prirozený.

Validita online aplikace je ověřována a používána konsorciem učitelů mateřských škol. Zvolili jsme cestu vytvoření funkční profesní komunity, která se bude na tvorbě spolupodílet. Zde se opíráme o myšlenku Westheimera o učící se profesní komunitě, která povyšuje profesní rozvoj jednotlivých členů na profesní učení v komunitním kontextu tzv. kolektivní učení (In Provázková Stolinská, 2020). S využitím online aplikace je totiž počíáno i v rámci vzdělávání budoucích učitelů mateřských škol.

Hlavním cílem developmentu, který jsme jako projekt získali v rámci TAČR, je vytvořit a výzkumně ověrit online aplikaci jako nástroj pedagogické diagnostiky připravenosti dětí $\mathrm{k}$ zahájení povinné školní docházky se zaměřením na rozvoj profesních kompetencí ${ }^{11}$ učitele MŠ. Zkvalitnit přípravu dětí na vstup do školy, a to dětí navštěvující MŠ i dětí v domácím předškolním vzdělávání. Přispět $\mathrm{k}$ zavádění moderních technologií do práce učitele MŠ.

Výstupem by měl být výzkumně ověřený nástroj pedagogické diagnostiky školní připravenosti v podobě online aplikace. Produkt a je originálem. Online aplikace má funkci odborné podpory učitele $\mathrm{v}$ pedagogické diagnostice. Má podpořit tvořivost učitele, zefektivnit jeho pedagogickou práci, ale i komunikaci s rodiči a jejich zapojení do práce MŠ. Aplikace nevede ke schematizaci, jako tomu nyní mnohdy bývá. (viz príloha Záznamové listy o dítěti).

Projekt $\mathrm{z}$ hlediska svého záměru vyžaduje spolupráci $\mathrm{v}$ rámci více oborů, $\mathrm{z}$ tohoto důvodu jsou zapojeny výzkumníci čtyř odborných pracovišt' Pedagogické fakulty UP v Olomouci a dále Pedagogické fakulty OU v Ostravě (Katedra pedagogické a školní psychologie).

\section{Aktuální fáze realizovaného developmentu}

Realizaci jsme rozdělili do pěti etap. $V$ první etapě jsme na základě teorie systémové pedagogiky tzv. otevřeného modelu výchovně vzdělávacího procesu, vytvořili koncepci online aplikace. Důraz jsme kladli na žádoucí souvztažnost všech systémotvorných komponent, relací i zákonitostí zvyšující integritu, kvalitu i efektivitu vzdělávání.

Na základě „modelu“ byly navrženy základní dimenze (škály) a tematické okruhy (v souladu s kurikulem).

Ve druhé etapě byla vytvořena online aplikace (technické zpracování). Aplikace byla následně ověřena $\mathrm{v}$ rámci pilotáže. Podstatou bylo ověřit porozumění položkám a nastaveným vývojovým škálám ze strany spolupracujících učitelů mateřských škol. Následně byly provedeny nezbytné korekce. Ve třetí etapě byla ověřovaná a postupně dotvářená online aplikace. Nyní se nacházíme ve čtvrté etapě, kdy je online aplikace implementovaná prostřednictvím aplikačních garantů (MŠ) do běžného pedagogického procesu. V závěru bude proveden ještě posttest, plánujeme analýzu činností výzkumného souboru a dotazování.

11 Do kterých zahrnujeme i kompetence z oblasti informačních technologií. Více např. Kubrický, Č́stková, 2015. 
Zde jako důležité vnímáme zaměření na rekognokaci praxe $\mathrm{v}$ reálném prostředí mateřských škol, kde se chceme zaměřit na popis každodenních situací s porozuměním $\mathrm{v}$ souvislostech. Poslední etapa je věnovaná vyhodnocení výzkumného ověření online aplikace v práci učitele MŠ.

\subsection{Online aplikace a její technologie}

Aplikace je primárně určena pro učitele mateřských škol a studenty programů pro předškolní vzdělávání. Aplikace prostřednictvím rozpracovaných dílčích kroků srozumitelně navádí učitele, jak postupovat při diagnostice dítěte a umožňuje komplexně nahlížet na jeho rozvoj v průběhu předškolního vzdělávání.

V průběhu řešení projektu probíhá registrace uživatelů pouze správcem, do systému tedy mají v současnosti př́stup pouze osoby zapojené do projektu, učitelé škol, kde probíhá ověřování aplikace.

Prvotní úloha učitelů spočívá ve vkládání základní identifikačních dat o dítěti (jméno dítěte a datum narození). Př́stup ke vkládaným údajům mají vždy pouze pedagogové mateřské školy, kam dítě dochází. V systému jsou rovněž uloženy údaje o školách, a to název, adresa a kontakty na školské zařízení a jména ověřujících učitelù.

Samotná diagnostika dítěte je strukturována dle vzdělávacích oblastí stanovených v předškolním kurikulu Dítě a jeho tělo, Dítě a jeho psychika, Dítě a ten druhý, Dítě a společnost, Dítě a svět. Je tak zajištěna konzistentnost cíl - vzdělávací oblasti - výstupy, klíčové kompetence.

Učitelé systematicky posuzují dosaženou úroveň dítěte $\mathrm{v}$ dílčích vzdělávacích podoblastech prostřednictvím indikátorů, ty představují tř̆ stupně naplnění, a to „zcela splňuje“, „,splňuje částečně“, „,spíše nesplňuje“, a stupeň „,nesplňuje“, do budoucna lze využít i jemnější stupně. Kvalitativní úroveň naplňování očekávaných výstupů je vymezena konkrétním popisem činnosti dítěte a $\mathrm{v}$ adekvátních prrípadech doplněna ilustrativními př́klady v podobě fotografíí.

V průběhu diagnostiky si učitelé sami volí oblasti, ve kterých plánují dítě diagnostikovat a současně určují frekvenci provádění této diagnostiky podle zvyklostí školy. Ke každému profilu dítěte je možné vložit dílčí poznámky učitele. Na základě vložených dat systém následně generuje přehledové tabulky a grafy do podoby souhrnné zprávy, kterou si učitel může vytisknout kdykoliv v průběhu vzdělávání a přiložit $\mathrm{k}$ dokumentaci dítěte. Poskytuje mu tak přehled o pokrocích či stagnaci dítěte při dosahování požadované úrovně. Zkušeným učitelům umožní přehledně evidovat a zobrazovat vývoj dítěte, méně zkušeným učitelům umožní nastavit komplexní a efektivní postup diagnostiky dětí.

Kromě učitelů provádějících diagnostiku dětí je do systému umožněn pasivní př́istup $i$ zákonným zástupcům dítěte. Ti nemohou údaje editovat, ale prostřednictvím vybraných informací o dítěti mohou získat zpětnou vazbu o průběhu jeho vzdělávání, vývoji i individuálních pokrocích. Prostřednictvím nabídky činností se tak rodiče mohou aktivně spolupodílet na vzdělávání dětí a podpořit práci učitele. Kontakt s rodiči může být př́nosný i pro rodiče dětí, jejichž dítě je zařazeno do domácího vzdělávání. Aplikace může sloužit i jako zásobník úkoli̊, ale i jako komunikační sít mezi rodiči a učiteli. Nastavení př́ístupu je již na volbě škol, či dohodě s rodiči. 


\section{Technické údaje o aplikaci}

Diagnostická aplikace je vytvořená jako webová aplikace. Její provoz zajišt’uje Serverové informační centrum Pedagogické fakulty. Evaluační systém projektu „Online aplikace jako nástroj pedagogické diagnostiky a intervence v práci učitele mateřské školy $\mathrm{s}$ akcentem na školní připravenost“ je multiplatformní webová aplikace vytvořená s cílem a orientací na jednoduchost, účelnost a uživatelskou prrívětivost ve vytváření, sdílení a vyhodnocování dat.

Hranice systému uzavírají databázi, navrženou a pracující s entitami obsahu vzdělávací oblast, výstupy oblasti a indikátory výstupu, a dále entitami hodnocení mateřská škola a dítě. $Z$ hlediska uživatelského přístupu zde existují role administrátora, pedagoga a koordinátora. Př́ístup do systému je možné skrze uživatelský účet. Veškerá data jsou chráněna a pravidelně zálohována.

Uživatelské rozhraní je vytvořeno na plně responsivním základu, tedy je možné aplikaci používat jak na mobilních dotykových zařízeních, tak na osobních počítačích. Serverová část je postavena na jazyku PHP a databázi MySQL, jádro aplikace využivá PHP framework Nette. Aplikace je postavena jako rostoucí, tzn. vyvíjející se na základě sběru požadavků od uživatelů - pedagogů zapojených MŠ a další pracovníků řešitelského kolektivu. Aplikace je dostupná standardně 24/7.

Data získávaná od zapojených pedagogů budou souhrnně automaticky reportována do přehledových sestav jak na úrovni jednotlivých entit, tak celkově vzhledem $\mathrm{k}$ plnění předpokládaných dílčích cílů projektu. Pro tento účel jsou připraveny grafické výstupy formou vícerozměrných grafů a tabulkových př̀hledů.

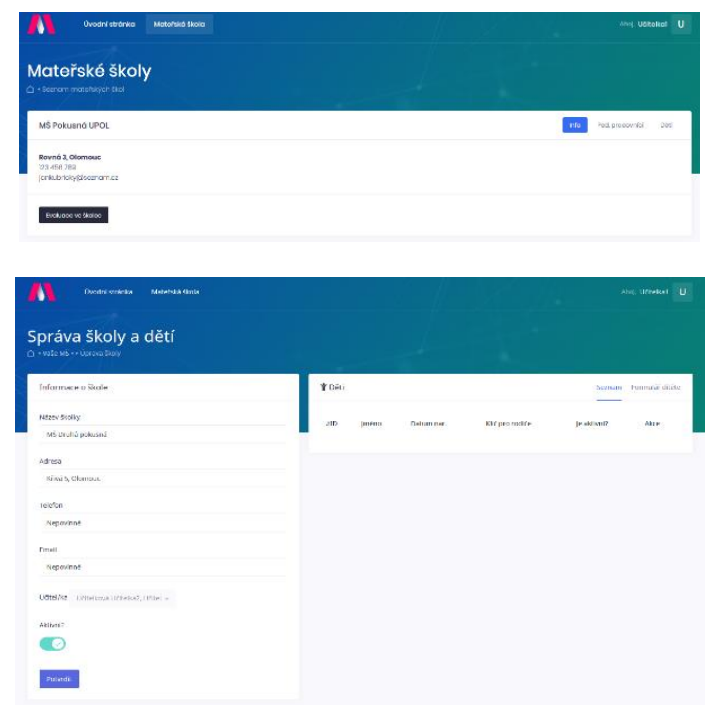



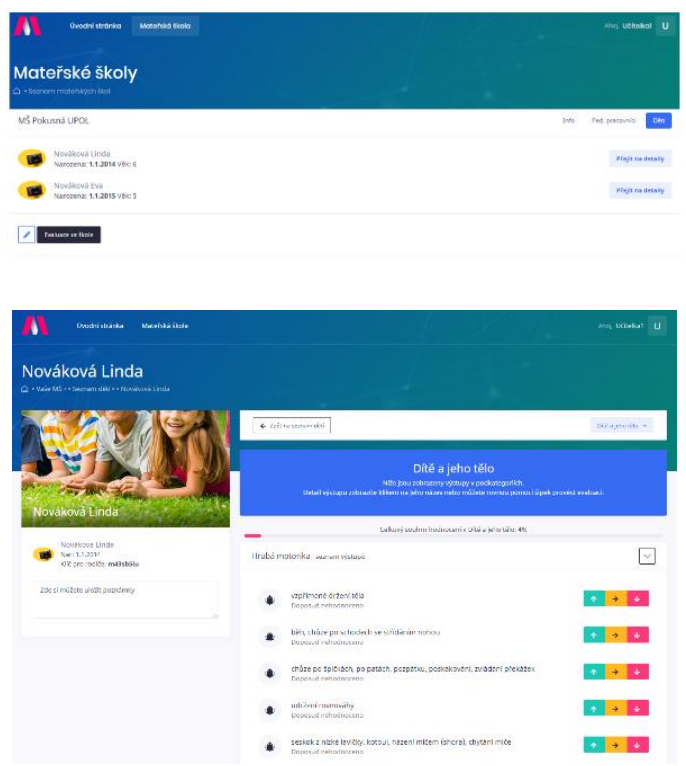

Obr. 1-4: Vizuál testovací verze webové aplikace:

\subsection{Reflexe ze strany učitelů mateřských škol}

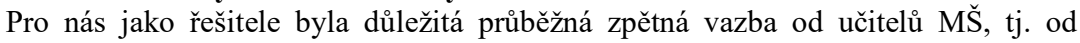
aplikačních garantů, kteří pracovali se základním modelem online aplikace několik měsíců, kdy došlo $\mathrm{k}$ jejímu ověřování. Pro práci v online aplikaci mají školy podrobný manuál, v př́ípadě nejasností mají možnost průběžných konzultací, a to jak z hlediska pedagogického, tak i technologického.

V čem spatřují učitelé hlavní klady online aplikace

- přehlednost, uživatelsky př́jemné, snadné vyplňování, výběr z možností zjednodušení práce učitele,

- výborná pomůcka pro začínající učitelku,

- výstupy jsou dostatečně popsané,

- je výborné, že se dá vygenerovat celkový přehled o dítěti a učitelka se může zaměřit na jednotlivé oblasti, kde dítě potřebuje pomoc, podporu.

Z přehledu může učitelka sestavit manuál pro práci a procvičování na doma - nap̌r. před zápisem. Popíše rodičům konkrétní výstupy, doporučí, jak s dítětem pracovat.

Za přínosné považujeme i připomínky a podněty pro zkvalitnění aplikace. Učitelé se vyjadřovali zejména $\mathrm{k}$ dílčím úpravám $\mathrm{v}$ rámci jednotlivých oblastí. Zamýšleli se nad obdobím, kdy má být pedagogický diagnostika zaznamenávaná prostřednictvím aplikace, 
a to na základě poznámek o dětech. Pokroky dítěte jsou v rámci online aplikace hodnoceny na třístupňové škále, zde se část učitelek zamýšlelo nad vhodností citlivějšího škálového hodnocení. Jak jsme se již zmínili, tř́i škálová stupnice byla zvolena spíše pro ověřování.

V současné době covidové epidemie, kdy řada dětí MŠ nenavštěvuje a zůstávají s rodiči doma, se aplikace ukazuje jako významný nástroj, jehož prostřednictvím učitel může řídit vzdělávací proces.

\section{Závěr}

Online aplikace je originálním produktem, její tvorba a ověření má vést k získání nových poznatků, tj. využití technologií $\mathrm{v}$ pedagogické diagnostice $\mathrm{v}$ předškolním vzdělávání. Z hlediska současného stavu poznání v dané oblasti se jedná o zcela nový produkt. Originalita a novost produktu směřuje k formulaci nových závěrů. Realizovaný development reaguje na potřeby praxe, což potvrzují nejenom naše několikaleté výzkumy, ale i výsledky šetření ČŠI. $Z$ hlediska vědou podpořené významnosti předškolního vzdělávání jako vzdělávací etapy v životě dítěte je řešené téma vysoce aktuální a zaslouží si řešení a podporu s využitím moderních technologií. Aplikace by měl být prostředkem rozvoje profesních kompetencí učitele MŠ v oblasti technické, ale současně podpoří rozvoj jeho kreativnosti a měkkých dovednosti. Z hlediska dítěte je aplikace přínosem pro zkvalitnění předškolního vzdělávání, což přispěje k rovnému přístupu ke vzdělávání dětí, které povinný předškolní ročník nenavštěvují nebo navštěvovat $\mathrm{z}$ různých důvodů nemohou. Rodičům umožní aktivnější spolupráci. Základem online aplikace je multidisciplinární přístup, kdy dochází propojení a sbližování znalostí pedagogiky, předškolní pedagogiky, didaktiky, diagnostiky, psychologie a technických oborů, což vede ke zvýšení synergického efektu při tvorbě produktu.

Článek vznikl za podpory TAČR v rámci řešení projektu TL02000346 Online aplikace jako nástroj pedagogické diagnostiky a intervence v práci učitele mateřské školy s akcentem na školní pripravenost.

\section{Literatura}

Kubrický, J., \& Částková, P. (2015). Teachers ICT Competence and their Structure as a Means of Developing Inquiry-based Education. Procedia-Social and Behavioral Sciences, 186, 882-885. https://doi.org/10.1016/j.sbspro.2015.04.071

Langmeier, J., Krejčířová, D. (2008). Vývojová psychologie. 2., aktualizované vydání. Praha: Grada Publishing. ISBN 80-247-1284-9.

Matějček, Z. (1994). Co děti nejvíc potřebují. Praha: Portál. ISBN: 978-80-262-0853-2

Provázková Stolinská, D. (2020). Komunikace učitele v prostředi české primární školy. Olomouc: UP, 2020. (v tisku)

Šmelová, E. (2019) Unreserved acceptance in chil'ds education. Olomouc. UP. ISBN 97880-244-5645-4.

Thorová, K. (2015). Vývojová psychologie. Praha: Portál. ISBN: 978-80-262-0714-6

Vágnerová, M. (1997). Psychologie problémového ditěte školního věku. Praha: Karolinum. ISBN 80-7184-488-8.

Vágnerová, M. (2005) Školní poradenská psychologie pro pedagogy. Praha: Karolinum. ISBN 80-246-1074-4. 